\title{
Improving the Ability of Addition for Mentally Retarted Students Using Counting Funnel Media
}

\author{
Sihadi, Gesang Walujoyati \\ SLB-C Negeri Pembina Prov. Kalimantan Selatan \\ Banjarbaru, South Borneo \\ sihadi64@gmail.com, gesang1402@gmail.com
}

\author{
Rohana \\ Special Education Study Program \\ Universitas Lambung Mangkurat \\ Banjarmasin, Indonesia \\ rohanaspd566@gmail.com
}

\begin{abstract}
This study aims to enhance the ability of addition counting operation from 1 to 10 for mental retardation students in the first grade of SLB-C Negeri Pembina of South Kalimantan Province using counting funnel media. The research method applied in this research was Classroom Action Research (CAR). The subjects were five mental retardation students in the first grade. The data was gathered using observation sheet of teacher and students' activity and analyzed using percentage. The result showed that the use of counting funnel media increases the process and the result of additional counting operation. The students' ability to count addition operation improved from $20 \%$ in the first cycle to $80 \%$ in the second cycles. Teacher's activities increased from $75 \%$ to $86.53 \%$ and the students' activities were also improved from $55 \%$ to $63 \%$ in the second cycles.
\end{abstract}

Keywords-counting funnel media, addition counting operation, mental retardation.

\section{INTRODUCTION}

Article 31 clause (1) in UUD 45 amendment states that "Every citizen has right for education". Referring to this statement, education is also for children with special needs. Education has a function to eliminate discrimination for children with special needs in order to gain the purpose of national education.

Children with special needs are children which have obstacles in physics, social, mental, or adaptive behavior and other temporary obstacles, so that to develop their potency will need special services or special education. One of the mental retardation children is children with below the average of normal children's intelligence. Those children are called mental retardation children [1]. Mental retardation children significantly have difficulties in adjusting themselves. Their mental abilities or IQ is below normal children (below score 70 on intelligence test). Mental retardation children are generally classified into three categories: light, medium, and heavy mental retardation. This classification used in Indonesia is in the accordance with [1] for light mental retardation children with the IQ in between 50-70. Those children can only follow the early step of academic capability like reading, writing, and applicative counting.

Counting is one aspect of studying mathematics. Mathematics itself is symbolic language which has practical function to express the quantitative and spatial relation. Some important reasons to study mathematics are to help the students to think logically based on the facts to solve daily life problems in relation with mathematics especially addition. Developing appropriate instruction for students with mild-tomoderate mental retardation is important when considering the postsecondary transition to adulthood [2].

From the observation, interviews, and tests on first grade mental retardation students in SLB-C Negeri Pembina South Kalimantan Province, some data were collected that there are students with difficulties when it comes to addition. From those facts, the researchers wanted to give solution to the classroom teachers so that the students can easily understand the addition count operation from 1 to 10 using the counting funnel media. The media that is used to give message that can arouse the mind in such a way that the process of teaching and studying can run effectively and efficiently as expected [3].

This counting funnel media is made in order to help increasing the mental retardation students' ability in understanding the number's addition. This media is a media that was inspired by the previous media which is often used as a learning aids namely the flannel board. Ref. [4] stated that addition learning outcomes of mentally retarded students using flannel board media is better than not using it.

Teaching mathematics to students with mental retardation is very challenging. Ref. [6] suggest that the concreterepresentational-abstract teaching sequeance coupled with strategy instruction can be used to teach multiplication facts to students with mental retardation. Some research aiming to teach children with mental retardation using concrete medias already giving positive affects to the children abilities.

A research in Batu City has the results indicate that the game of numeric train has a good effect on the ability to calculate sums of 1-10 students of mental retardation [7]. A study using a smart flannel board media affect the ability to calculate the number of mentally retarded children in Malang City [8]. The most relevant reaseach was the one in Mojokerto, using funnel count media, which gave a positive affects to the ability od counting for students with Mild Intellectual disabilities [9]. Hence, through this media, the researchers wanted to involve the students to be more active in studying, and to help the understanding of counting addition from 1 to 10 . 
This research aims (1) to enhance the ability in addition count operation of first grade mental retardation students; and (2) to improve teacher and students' activities in studying mathematics especially in addition concept using counting funnel media for the first grade students with mental retardation.

\section{METHOD}

This research is held on the first grade students who have mental retardation in SLB-C Negeri Pembina South Kalimantan Province. This research used Classroom Action Research (CAR) conducted in the classroom. The steps of the research were: (1) planning, (2) implementation, (3) observation, (4) reflection [5]. The research's design can be seen on Figure 1:

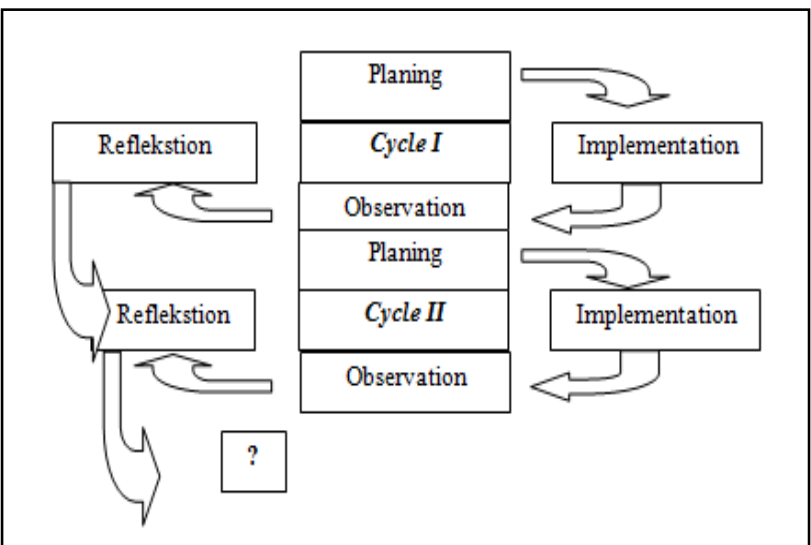

Fig. 1. The Steps of CAR

According to [5] the steps in preparation Classroom Action Research (CAR) are:

\section{A. Step 1: Planning}

In this step, the researchers explain what, why, when, where, by whom, and how the research will be done. In arranging this research, the researchers determine the spot or the focus of event that will need special attention to be examined, and then making an observation instrument to help the researchers in gathering facts when the action takes place.

\section{B. Step 2: Implementation}

The implementation of this research is implementing the content of the design, that is using action in the classroom. Things to remember are in this second step the teacher must remember and obey things that have been defined in the design; however, the teachers also need to act naturally in the action.

\section{Step 3: Observation}

The observation by the researcher is when the action takes place. So, the two activities are done at the same time.

\section{Step 4: Reflection}

This step is meant to study the thorough action based on the collected data, and then evaluation is done to complement the next step.
These four steps in the research actions are the elements to make a new cycle, one of a series actions, which will go back to the first step. Therefore, a cycle is planning design of the research to the reflection which leads to evaluation.

\section{Result AND Discussions}

This Classroom Action Research is held in two cycles in which every cycle contains two meetings in the classroom using the counting funnel media in addition operation of mathematics from 1 to 10 . Every meeting concerning the teacher and students' activities and the evaluation of addition count operation.

Based on the observation result, teacher's and students' activities during the treatment can be seen in Fig. 2 and Fig. 3 .

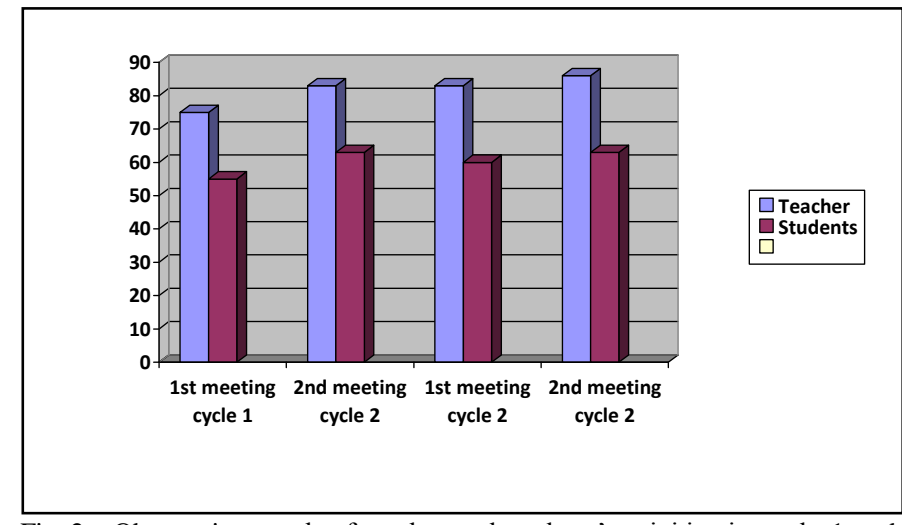

Fig. 2. Observation result of teacher and students' activities in cycle 1 and cycle 2 .

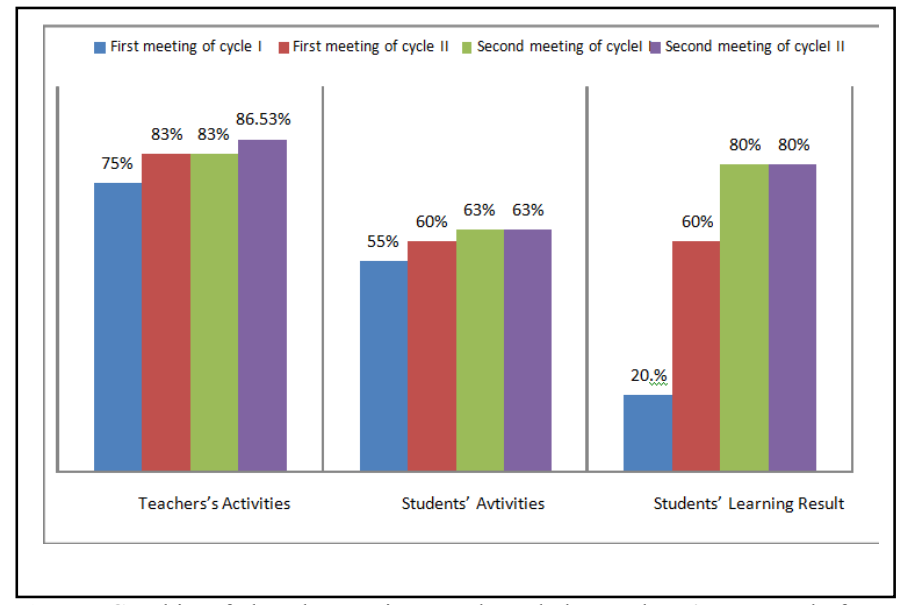

Fig. 3. Graphic of the observasion result and the students' test result from Cycle I and Cycle II

Based on Fig.3, the teacher had done all the activities on the lesson plan; however, on some aspects are not maximal. On the other hand, the students' activities had increased.

Beside teacher and students' activities, the data of students' achievement was also found in this study. This was inferred in Fig.4. 


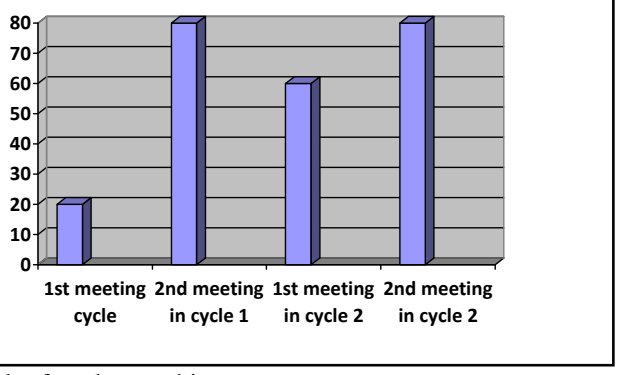

Fig. 4. The result of students achievement

\section{A. Cycle I}

\section{1) Teacher's Activities}

Considering the score gained by the students on Cycle I were already increasing, the teacher still had to fix some aspects that were not still maximal. On the next cycle, the teacher was expected to fix the learning on those aspects.

\section{2) Students'Activities}

From the five students on the learning time, the result of observation on Cycle I still showed some activities that were not as expected, there were still some students got low score in some aspects. However, on the second meeting there were a little bit increasing on students' activeness.

\section{3) Learning Result}

On the first meeting of Cycle I, the learning result of the students were not yet successful, since there were still 4 students could not gain the minimal score. The score result $\geq$ 65 was only one student or $20 \%$. On this second meeting, the learning result of the students can be said successful, since the result gained by the students are above the successful indicator that is determined 65. On this second meeting, the students that had score $\geq 65$ are three students or $60 \%$ and there were two students had score $<65$ or $40 \%$.

Based on that finding above, the researchers would do research on Cycle II. It is hoped that the collaborator teacher would fix some aspects that were not maximal so that the learning process and the learning result could be optimal.

\section{B. Cycle II}

\section{1) Teacher's Activities}

Fig. 2 and Fig. 3 show that the teacher had done all the activities on the lesson plan consistently with the previous meeting; however, there were still some aspects yet to be done, it will need some more improvement.

\section{2) Students' Activities}

Based on the data gathered from the observation of the observers/researchers on this research, the students' activities in the learning process were good and stable.

\section{3) Learning Result}

Based on the test/evaluation result in the end of every learning on the first and second meeting of Cycle II, the learning test result can be seen on the graphics above. Based on the data gained from the picture above, it can be seen that the students learning result had increased on Cycle II compared to the previous meetings. It can be seen clearly on the graphic above that the scores of the five students had reached the completion $80 \%$ even though there was one student still cannot reach the completion, however there was an improvement than the previous meeting.

\section{4) Reflection}

This Classroom Action Research is concerning the activities of teacher and students learning and also the scores on Cycle I and Cycle II. There were some improvements through fixing some aspects on Cycle II. There is one students that could not complete the score. It is a particular achievement. It is hoped there are improvement from one meeting to another meeting.

\section{DISCUSSION}

The result of the research on the classroom of the first grade of the mental retardation students on SLB-C Negeri Pembina in mathematics for the addition count operation from 1 to 10 using the counting funnel media showed some improvements on the learning result of the students. The improvements are not only because of the media but also the role of the teacher in the classroom and how the teacher managed the classroom. Therefore, it is not only the learning result of the students that is increasing but also the situation on the classroom comes alive because of the contribution of the teacher and also the students.

The following is the description of the result of the research in the two cycles or four meetings which include the teacher's activities, the students' activities and the students learning result. The students activities are improved because of the teacher's activeness had also improved. This proved that the activeness of a teacher in the classroom has a big effect into the students' activeness. Since the teacher's activeness increased, the students' activeness also increased. The students' activeness had increased from the first meeting to the second meeting on Cycle I and stable on the first meeting and the second meeting on Cycle II. Then, the learning result also increased from the first meeting. In Cycle I, there was $20 \%$ or only one student who got the score above the minimal completeness score, the same result with the pre test score. On the second meeting in Cycle I, the score had increased into $60 \%$ or there were three students had the score above the minimal completeness score. Then, on the first meeting in Cycle II, there was one more student who gained the score above the minimal completeness score. It became $80 \%$ or there were 4 students who gain the completeness score. Those things are described on the graphic of the result of the research from Cycle I to Cycle II. The results are just in accordance to other reseach that used a media to teach students with mental retardation [6].

\section{CONCLUSION}

The learning of addition count operation on the first grade mental retardation students worked well using the counting funnel media, marked by the increasing of the teacher and students' activities and the students' learning result. The learning of mental retardation students on the grade below 
should be taught using a media because the ability of the students is still abstract.

\section{REFERENCES}

[1] Republic of Indonesia. Peraturan Pemerintah No. 72 Tahun 1991 tentang Pendidikan Luar Biasa. Jakarta: Sekretariat Negara, 1991.

[2] F. M. Butler, S. P. Miller, L. Kit-hung, and T. Pierce, "Teaching Mathematics to Students With Mild-to-Moderate Mental Retardation: A Review of the Literature," Mental Retardation, vol. 29, no. 1, pp. 20-31, Feb. 2001.

[3] Sudirman, Media Pembelajaran. Jakarta: Raja Grafindo Persada, 2002.

[4] A. Hayumahastuti, "Pengaruh Penggunaan Papan Flanel Geometri Terhadap Kemampuan Penjumlahan Pada Siswa Tunagrahita Ringan Kelas IV SDLB B/C Kepanjen," Thesis, Fakultas Ilmu Pendidikan, Universitas Negeri Malang, Malang, Indonesia, 2016.

[5] S. Arikunto, Penelitian Tindakan Kelas Edisi. Jakarta: Bumi Aksar, 2015.
[6] V. Morin and S. Miller, "Teaching Multiplication to Middle School Students With Mental Retardation," Education and Treatment of Children, vol. 21, no. 1, pp. 22-36, 1998. Available: http://www.jstor. org/stable/42899519 [Accessed October 10, 2018]

[7] A. Rachmawati, "Pengaruh Permainan Kereta Angka Terhadap Kemampuan Berhitung Penjumlahan Siswa Tunagrahita Kelas II di SDLB Eka Mandiri Kota Batu," Thesis, Fakultas Ilmu Pendidikan, Universitas Negeri Malang, Malang, Indonesia, 2015.

[8] M. Ludfi, "Pengaruh Penggunaan Media Papan Flanel Pintar Terhadap Kemampuan Berhitung Penjumlahan Anak Tunagrahita Kelas 3 SDLB Kedung Kandang Kota Malang," Thesis, Fakultas Ilmu Pendidikan, Universitas Negeri Malang, Malang, Indonesia, 2015.

[9] D. B. Lestari, "Pengaruh Penggunaan Media Corong Hitung Terhadap Kemampuan Berhitung Siswa Tunagrahita Ringan SLB PGRI Dlanggu Mojokerto," Thesis, Fakultas Ilmu Pendidikan, Universitas Negeri Malang, Malang, Indonesia, 2017. 